\title{
IAMJ
}

INTERNATIONAL

AYURVEDIC

MEDICAL JOURNAL

\section{PHARMACEUTICAL PREPARATION OF VRANAROPANI MALAHARA AND ITS ANALYTICAL EVALUATION}

\author{
Arsha K P ${ }^{1}$, Suresh Y ${ }^{2}$, Subrahmanya Padyana ${ }^{3}$ \\ ${ }^{1}$ III YR B.A.M.S, Alva's Ayurveda Medical College, \\ ${ }^{2}$ Associate Professor, Dept. of PG Studies in Agada Tantra, \\ ${ }^{3}$ Director, Alva's Traditional Medicine Archive (ATMA) \& Research Centre, \\ Alva's Ayurveda Medical College, Moodubidire, Karnataka
}

Email: arshakp1098@gmail.com

\section{https://doi.org/10.46607/iamjp04042020}

(Published online: May 2020)

Open Access

(C) International Ayurvedic Medical Journal, India 2020

Article Received: 27/03/2020 - Peer Reviewed: 07/05/2020 - Accepted for Publication: 23/05/2020

\section{Check for updates}

\begin{abstract}
Vrana (wound) is an oldest ailment from which the mankind is suffering since its origin. Wound healing has become a major concern in the health care system. The financial and social impact imposed by chronic wound on society is substantial. Apart from classical references, a vast majority depends on folklore medicines. This study aims at introduction of one such efficient, wound healing ethno-medicine, Vranaropani (Hemigraphis colorataAcanthaceae), and its modification into Malahara form. Taila was prepared from the drug Vranaropani. To overcome the inconvenience of extraction as well as for better enhancement of efficacy, shelf life and acceptability, Vranaropani Malahara was prepared. Analytical study carried out to standardize the preparation. Light brown coloured, homogenous Malahara with strong smell of Siktha was obtained. The $\mathrm{pH}$ value was 7.4. Spreadability value was 12 . Extrudability study findings were good. Thermal stability value was $40-45^{\circ} \mathrm{C}$. Loss on drying value was $2.7 \%$. Through this study, a folklore drug was explored and modified into an acceptable form. The result of analytical study was found to be encouraging and it can be taken up for clinical study.
\end{abstract}

Keywords: Vranaropani, Vrana, Malahara, Wound healing 


\section{INTRODUCTION}

A wound can be defined as a disruption in the continuity of epithelial lining of skin or mucosa. It happens relatively quickly in which the skin is torn, cut or punctured or where blunt force or trauma causes a contusion. As per Ayuvedic perspective, Acharya Susrutha in Susrutha Chikitsa, - explains Vrana (wound) is derived from the root 'Vran', which means splitting or tearing the body or that which causes discontinuity in the body ${ }^{1}$. According to a statistical survey in India, cutaneous wounds have an incidence of 15 per 1000; in which 10.5 corresponds to acute cases while 4.5 are chronic ${ }^{2}$. Wound healing is a complex process in which the skin and the tissues under it repair themselves after injury. Skin is a protective barrier of our body and any hindrance in its continuity is a major health issue. Wound healing has many challenges like oxygenation, infections, age, sex hormones, stress, diabetics, obesity, medications, alcoholism, smoking and nutrition. It is estimated that $1-2 \%$ of the population in developed countries will suffer from chronic wounds in their lifetime. Patients with chronic wounds may experience chronic pain, loss of function and mobility, increased social stress and isolation, depression and anxiety, prolonged hospitalization, increased financial burden, increased morbidity and mortality. The impact of chronic wounds on the health and quality of life of patients and their families should not be underestimated. This shows need of an effective management of wounds.

Apart from classical references, a vast majority of people depends on folklore methods. Vranaropani ${ }^{3}$ (Hemigraphis colorata - Acanthaceae family), known as Murikootti in Malayalam, is one such drug widely used by folklore practitioners of villages of Kerala and Karnataka, as a remedy for wound. The fresh leaves are crushed and the extract (Swarasa) is applied over the affected part. But due to the inconvenience of this method, there is a need for the pharmaceutical modification of the same, for better enhancement of efficacy, shelf life and acceptability. With such an intension, the study has been undertaken to prepare a Malahara (ointment) from Vranaropani.

\section{Materials and Methods}

\section{Identification and collection of drugs}

Fresh leaves of Vranaropani (Hemigraphis colorata Acanthaceae family), was procured from authentic source in local areas of Kannur, Kerala. Cleaned well and washed.

II. Pharmaceuical preparation: Pharmaceutical preparations such as Vranaropani Taila and Vranaropani Malahara was carried out under the supervision of experts from the Rasashastra and Bhaishajya Kalpana Lab, Alva's Ayurveda Medical College, Moodubidire.

Vranaropani Taila: The preparation was carried out as per classical references of Taila Kalpana. ${ }^{\mathbf{4}, 5}$ Kalka (paste of raw drug) and Swarasa (fresh leaf extract) was taken from the same drug. Coconut oil was used as Sneha Dravya in the preparation. The preparation was carried out in mild intensity of fire, with frequent stirring, till the attainment of Taila Paka Sidhi Lakshana. Further it was filtered using a clean cloth, preserved in an airtight container. The ingredients of the Vranaropani Taila are depicted in Table. 1.

Vranaropani Malahara: Vranaropani Malahara is a modified preparation without any classical references. The procedures were according to the rules of Malahara Kalpana ${ }^{6}$. The ratio followed was 1:6. To Vranaropani Taila, small pieces of bee's wax was slowly added and stirred carefully. Preparation was carried out in mild intensity fire. After complete dissolution of wax, filtered properly using a clean cloth. The Malahara was later filled into the tubes. The composition of Vranaropani Malahara is depicted in Table 2.

\section{Analytical study}

A study can never be valued without any scientific basis. Standardization of herbal medicine has become the present-day need. To achieve this, one must carry out necessary analysis to detect any factors which hinders the genuinity of the product. Analytical studies were carried out from Srinivas College of Pharmacy, Valachil, Mangaluru, according to standard procedures of Laboratory guide for analysis of Ayurveda 
and Sidhha formulations ${ }^{7}$. The parameters considered for analysis includes:

Organoleptic evaluation: Carried out by sensory organs. It includes:

1. Sparsha- consistency,

2. Rupa - appearance, colour,

3. Gandha - odour
Physico- chemical evaluation: This includes:

1. Loss on drying,

2. Determination of $\mathrm{pH}$,

3. Spreadability,

4. Extrudability study,

5. Microbial contamination

\section{Topical sensitivity test}

\section{RESULTS}

Pharmaceutical preparation

Table 1: Ingredients of Vranaropani Taila

\begin{tabular}{|l|l|l|l|}
\hline Sl.No & Ingredients & Quantity Used & Quantity Obtained \\
\hline 1 & Vranaropani Kalka & $625 \mathrm{G}$ & \multirow{2}{*}{$4.2 \mathrm{~L}$} \\
\hline 2 & Vranaropani Swarasa & $20 \mathrm{~L}$ & \\
\hline 3 & Narikela Taila & $5 \mathrm{~L}$ & \\
\hline
\end{tabular}

Table 2: Ingredients of Vranaropani Malahara

\begin{tabular}{|l|l|l|l|c|}
\hline S1.No & Ingredients & Ratio & Quantity Used & Quantity Obtained \\
\hline 1 & Vranaropani Taila & 6 Parts & $2000 \mathrm{ML}$ & \\
\hline 2 & Beeswax & 1 Part & $335 \mathrm{G}$ & $1980 \mathrm{G}$ \\
\hline
\end{tabular}

\section{Organoleptic Characters}

Table 3: Organoleptic Characters:

\begin{tabular}{|l|l|}
\hline Parameters & Results \\
\hline Colour & Light Brown \\
\hline Odour & Strong Characteristic Odour Of Siktha \\
\hline Consistency & Homogenous and Free From Lumps \\
\hline \multicolumn{2}{|l}{} \\
\multicolumn{1}{|l}{ Table 4: Physico- Chemical Analysis: } & \multicolumn{1}{l}{} \\
\hline Parameters & Results \\
\hline pH & 7.4 \\
\hline Spreadability $(\mathrm{Gm} \cdot \mathrm{Cm} / \mathrm{S})$ & 12 \\
\hline Extrudability Study $(\mathrm{G})$ & 180 \\
\hline Thermal Stability $\left({ }^{0} \mathrm{C}\right)$ & $40-45^{0} \mathrm{C}$ \\
\hline Loss On Drying $\left(\mathrm{At} 3 \mathrm{hr} / 105^{\circ} \mathrm{C}\right)$ & $2.7 \% \mathrm{~W} / \mathrm{W}$ \\
\hline Microbial Contamination & 18 Colonies of Bacteria \\
\hline
\end{tabular}


Topical Sensitivity Test: Negative.

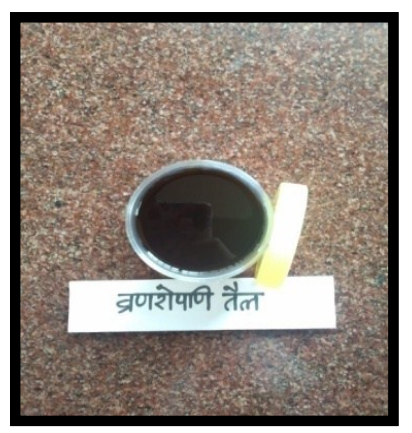

Fig1: Vranaropani Taila

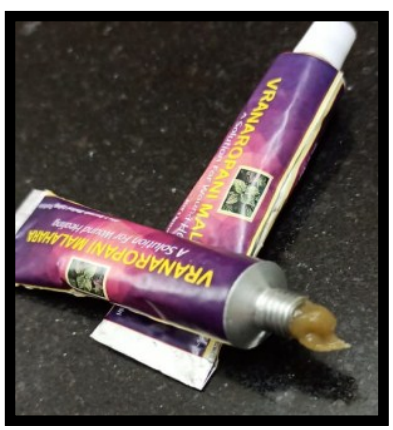

Fig2: Vranaropani Malahara

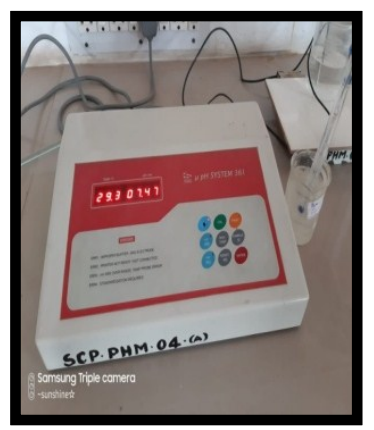

Fig3: $\mathrm{pH}$

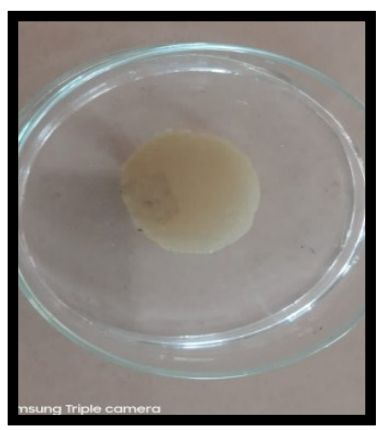

Fig.4 Spreadability

\section{DISCUSSION}

Drug: Vranaropani is an ethno-medicinal plant that promotes healing of wound. This possesses considerable number of phytochemical constituents that can be used for various medicinal purposes. Studies proved its pharmacological effects like anti-bacterial, antiinflammatory, antioxidant and wound healing property. ${ }^{8,9}$ The relevance of selecting this drug includes its efficacy, acceptability and its wide availability.

\section{Pharmaceutical preparation:}

In Taila preparation, the Kalka and Swarasa were taken from the same drug itself, as the fresh leaf extract of Vranaropani is used in folklore. The ingredients; Kalka: Snehadravya: Swarasa was taken in the ratio 1/8:1:4. ${ }^{\mathbf{1 0}}$ Coconut oil (Narikela Taila) was used as the Sneha Dravya. Taila Paka was carried out for 3 days as Swarasa was taken as Drava Dravya. Throughout the procedure, mild intensity fire and frequent stirring was followed. Taila with Madhyama Paka was collected after observing proper Paka Lakshana. In Malahara preparation, Siktha and Vranaropani Taila was taken in the ratio 1:6, as this ratio yield a product with good consistency. A homogeneous butter like substance with light brown colour was obtained.

\section{Analytical study:}

Quality of medicine is very important in health care system. Various analytical studies were carried out, to check the genuinity of the product.

The organoleptic study provides a basic idea about the quality of formulation. The characters were evaluated by using sense organs. The colour of prepared Mala- hara was light brown. It had specific smell of beeswax as it was used as the base of Malahara. It was good in consistency, homogeneous and free from lumps. The results of analysis were satisfactory. The $\mathrm{pH}$ value obtained was 7.4. The slight alkalinity may be due to the presence of coconut oil and beeswax used in the preparation. To justify the variation from the normal $\mathrm{pH}$ range, topical sensitivity test was carried out ${ }^{11}$. This is done to check any possibilities of developing skin irritation or other adverse reaction by topical application of the formulation. Malahara was applied to the elbow of the hand and observed for any side effects like skin inflammation, irritation, reddening of skin (allergic reaction) etc. The result was negative i.e. it is non - irritating to skin. Spreadability denotes the extent of area to which the cream or ointment spreads on application to skin or the affected part. The value was found to be 12 . It shows the ointment is having fast spreading nature and good for application. Thermal stability determines the likelihood of a material to undergo phase transitions in response to thermal stress which may occur due to manufacturing process or storage conditions. Malahara shows a temperature range of $40-45^{\circ} \mathrm{C}$. Extrudability is the measure of force required to extrude the material from a collapsible tube when certain amount of force has been applied on it in the form of weight. The value signifies, the percent of ointment extruded was good. Loss on drying at $105^{\circ} \mathrm{C}$ indicates the presence of all evaporating solvents along with water. Higher the moisture content more will be the percentage of loss on drying of the substance. The value obtained was 
$2.7 \%$ which shows less water content in the product. The formulation was subjected to microbial contamination study to rule out the presence of pathogens in the preparation which may affect the efficacy and stability of product. The result revealed that the product contains 18 colonies of bacteria. It was difficult to suppress all microbes as the base is oil, it gives protection to microbes. The result shows low contamination of Malahara. These microbes may enhance the wound healing process which may be studied in further research.

\section{CONCLUSION}

Malahara of a folklore drug Vranaropani was prepared and standardized on the basis of phytochemical analysis. The results obtained in the present study were found to be encouraging. The inconvenience of using crude drug can be satisfied, as this study focuses on the preparation of Malahara, which is acceptable, easily available as well as has more shelf life. Traditional medicine lives among people as part of their culture. Exploring them and proving them scientifically is essential. Here one such drug Vranaropani is identified. Further experimental and clinical evaluation can be carried out considering the current study.

\section{REFERENCES}

1. Acharya Susrutha - Susrutha Samhitha, with Nibhandhasangraha commentary of Dalhana Acharya and Nyaya chandrikapanjika of Sri Gayadasa Acharya of Nidanasthana,Vaidya Yadavji Trikamji Acharya Chowkhamba Krishnadas Academy, page.no:393

2. Thakre Rushikesh Bhutadas, Chouragade B, Khobragade P, Harne Ketaki, Unexplored wound healing property of Ehtritia laevis Roxb. (Khandu Chakka) PLANT, IJRAP, Sep-Oct 2016, (Suppl.4), page no. 5457

3. Itoozhi Ayurveda - Ayurveda Herbs Garden published on September 16,2014. www.keralaayurvedics.com/herbs-plants.

4. Sarangadara- Sarangadara Samhitha, translated by Dr. Himasagara Chandra Murthy, Chowkamba Sanskrit Series Office publications, Sneha Kalpana Adhyaya, page no:199
5. Taila, The Ayurvedic Formulary of India, Part II, published by Govt. of India, page no. 133

6. Dr. Ravindra Angadi, Textbook of Bhaishajya Kalpana Vijnana, Chaukhamba Surbharati Prakashan, Varanasi, Sikthataila. Malahara, Upanaha and other Kalpanas, page no:360-362

7. The Ayurvedic Pharmacoepia of India, Part II (Formulations), 2007, published by Ministry of AYUSH, Govt. of India.

8. Niya Panthalookaran, K. Krishnakumar, Hareesh Babu E- A Review on Pharmacological effect of Hemigraphis colorata, SAJP,2017,6(3): 98-100.

9. Subramanion A, Evans DA, Rajasekharan S, Nair GS, Effect on Hemigraphis colorata (Blume), HG. Hallier, leaf on wound healing and inflammation in mice, Indian Journal of Pharmacology,2001 Jul.1:33(4)-283285.

10. Sarangadara- Sarangadara Samhitha, translated by Dr. Himasagara Chandra Murthy, Chowkamba Sanskrit Series Office publications, Sneha Kalpana Adhyaya, page no:199

11. N. Nayana, B K. Prashanth, Formulation development and preliminary physio-chemical characterization of Vatapatradi Malahara: a modification, IJRAP,2015 Nov- Dec: 6(6): 676-681.

\section{Source of Support: Nil Conflict of Interest: None Declared}

How to cite this URL: Arsha K P: Pharmaceutical Preparation of Vranaropani Malahara and its Analytical Evaluation. International Ayurvedic Medical Journal \{online\} 2020 \{cited May, 2020\} Available from: http://www.iamj.in/posts/images/upload/2293 2297.pdf 